placed among the Braconidæ in a subfamily which he called Setphaninæ.

Mr. Uhler made some remarks on the 'schlussfeld ' of certain Cicadidæ, tracing the development of this basal fold in the hind wings throughout Cicadas from many parts of the world and suggesting its connection with the rapidity of flight of the species. Mr. Benton spoke of the proposed introduction of Apis dorsata into the United States, giving an account of previous attempts and particularly of his own journey some years ago to Ceylon in search of this giant bee of India. He described the methods by which he secured colonies and gave an account of the habits of the bee and the character of its nests. He desired the opinion of the Society as to the possibility of the successful introduction of this bee into the United States and the desirability of such introduction. The paper was briefly discussed by Messrs. Mann, Skinner, Schwarz, Ashmead and Stiles.

L. O. HowaRD, Secretary.

\section{NEW YORK SECTION OF THE AMERICAN CHEMICAL SOCIETY.}

AT the meeting of the Section held on the 10th inst, at the College of the City of New York, Prof. Birchmore exhibited on the screen the absorption spectra of a number of aniline and other colors, including eosin, aniline red ultramarines, potassium permanganate, cudbear, etc., and explained the effect of certain reactions with ammonia and other reagents on the size and position of the absorption bands.

Dr. Birchmore also explained an arrangement of adjustable colored prisms projecting through the opposite sides of a cylinder, to be filled with a liquid having the same refractive index as glass : oil of juniper was mentioned; whereby the colors of the Nessler reagent in ammonia determinations could be recorded.

The description of this apparatus was brought out in the discussion of Dr. Albert R. Leeds' paper on 'Standard Prisms in Water Analysis, and the Valuation of Color in Potable Waters,' in which Dr. Leeds described his first attempts nearly twenty years ago to obtain suitable standards of comparison, using solutions of various kinds, colored glass plates and colored glass prisms. He reviewed the progress which has been made in the matter, and recommended the appointment of a committee to unify the methods and adopt a standard.

Prof. C. L. Speyers read a paper on 'Matter and Energy,' in which he discussed the more recent views of Ostwald.

Dr. E. G. Love exhibited some remarkably fine microphotographs of several varieties of starch.

Dr. L. Saarbach exhibited an improved form of laboratory temperature regulator, which has not only the advantage of small cost, but can be taken apart, cleaned and adjusted with the greatest ease. It may be arranged for high or low temperatures and for almost any degree of sensitiveness. It is practically an air thermometer, but can be adjusted to different degrees of sensitiveness by replacing more or less air, by mercury.

Prof. Breneman, chairman of the committee appointed to consider the organization of a chemical club, reported that he had received nearly a hundred replies to the circular sent out, all but about twenty of which were unqualifiedIy in favor of the project. He stated that there had been a misunderstanding on the part of some as to the intended membership, and he desired to have it known that there is no intention of limiting the membership to any society or section of the chemical fraternity, but to include chemists and chemical manufacturers generally.

Durand Woodman, Secretary.

GEOLOGICAL CONFERENCE OF HARVARD UNIVERSITY, MARCH 31, 1896.

'Longshore Transportation on the North Jersey Coast. J. Edmund Woodman.

Littoral transportation is caused by wind waves, wind currents, tidal waves and tidal currents. 'All these factors are in active operation on the Jersey coast, but the proof is very strong that the controlling forces are tidal. The most general statement of this proof is that the winds, which must be uniform over a considerable extent of shore, act in some places in conjunction with the transportation, in others in opposition to it.

From the region east of Toms river to Sandy 
Hook there is a dominant northward current; from the former place to Delaware bay a southward one. This current can be seen and traced in many places. Its geographic effect is chiefly the migration of material (and hence of inlets) from the center towards the two extremities of the State. This opposition of movement cannot be due to the fact that the northern half is in the lee of Long Island, and thus while northeast winds dominate farther south they are overpowered by southeast winds there, for at Sandy Hook or Long Branch the northeast storms are as severe as at Atlantic City.

The reason given by the U. S. C. S. (1856) for this northward movement cannot be correct; for upon examining the region we see that ever so strong a draught through False Hook channel would not cause a steady and strong current as far south as Manasquan inlet. The explanation must be sought in the effect of submarine topography upon the tides, which near shore move as waves of translation. This effect seems to be chiefly the formation of nodal points of secondary importance in the three great tidal bays of the Atlantic coast. The same phenomenon occurs on the south shore of Long Island, and on the east shore of Cape Cod. These secondary nodes are joints of divergence of currents, and must be caused by inequalites of the great continental delta which we do not now recognize.

While the author considers tidal action to be dominant here, he does not believe it to be the exclusive agent of transformation. The direction and amount depend upon the resultant of all the factors tending to produce movement, and wind waves form a veryconsiderable element in this. But that wind waves do not control it is proved by the fact that the current continues northward against adverse winds, and can only be momentarily reversed by long continued and violent storms.

Transportation is mainly off-shore, by bar migration; but a small amount can be observed along the strand, demonstrably propelled by currents and not by waves. Most of the movement here, however, is caused by wave impact and the reflex flow of water.

The deposition is little affected by currents, for much of it is made upon the outside of Sandy
Hook, at a place where the current enters the mouth of False Hook channel, and hence is, if anything, stronger than farther south. But with a constant current deposition often varies with direction and intensity of wind.

It is worthy of note that the point of divergence of the northward and southward currents is so located that the wing, Sandy Hook, is receiving all the waste from the wearing-back of the soft headland of Cretaceous and Tertiary age which extends from Bay Head to Low Moor; while of the transportation along the barrier beaches southward none comes from the headland. Thus these beaches are only carrying their own detritus, piled up at an earlier stage, and are wasting themselves away.

$$
\begin{aligned}
& \text { T. A. JAGGAR, JR., } \\
& \text { Recording Secretary. }
\end{aligned}
$$

THE ACADEMY OF SCIENCE OF ST. LOUIS.

AT the meeting of April 20th Dr. C. M. Woodward presented the results of a study of certain statistics of school attendance, from which it appeared that the average age of withdrawal from the public schools in three cities compared was as follows: Boston, 15.8 ; Chicago, 14.6 ; St. Louis, 13.7.

Prof. J. H. Kinealy exhibited and gave a mathematical discussion of the Stang planimeter, an interesting and simple instrument of Danish invention, but improved in the United States.

William Trelease, Recording Secretary.

\section{NEW BOOKS}

A History of the Warfare of Science with Theology in Cristendom. ANDREW D. WHITE. New York, D. Appleton \& Co. 1896. Vol. I., pp. xxiii+415; vol. II., pp. xxiii +474. \$5.00.

A Dictionary of Chemical Solubilities. ARTHUR Messinger Comey. London and New York, Macmillan \& Co. 1896. Pp. $\mathrm{xx}+515$. \$5.00.

Current Superstitions. FANNY D. BERGEN. Boston and New York, published for the American Folk-Lore Society by Houghton, Mifflin \& Co. 1896. Pp. $\mathrm{x}+161$.

Plane and Solid Geometry. C. A. VAN VeLtzer and George G. Shutts. Madison, Wis., Tracy, Gibbs \& Co. Pp. viii +395 . 